\title{
Implementasi Kurikulum 2013 Revisi 2016 Pada Pembelajaran Menulis Teks Anekdot
}

\author{
Rasyid Manshur ${ }^{\mathrm{a} 1}$, Sarwiji Suwandi ${ }^{\mathrm{a} 2}$, dan Suyitno ${ }^{\mathrm{a} 3}$ \\ ${ }^{a}$ Universitas Sebelas Maret Surakarta \\ ${ }^{1}$ rasyidmanshur14@yahoo.com, ${ }^{2}$ sarwijiswan@staff.uns.ac.id, ${ }^{3}$ suyitno@staff.uns.ac.id
}

\begin{tabular}{l} 
Article info \\
\hline Article history: \\
Received: $25-09-2017$ \\
Revised : 10-10-2018 \\
Accepted: 12-12-2018
\end{tabular}

Keywords: anecdote curriculum students text writing

\section{A B S T R A C T}

The objectives of this research are to describe and explain (1) the process of writing anecdote text based on the 2013 Curriculum and its 2016 revision conducted by the teachers of Indonesia Language subjects in class X SMK Negeri 1 Gondang Sragen, (2) the existing obstacles in the process of writing anecdote text of the 2013 Curriculum and its 2016 revision in class X SMK Negeri 1 Gondang Sragen, and 3) the teachers' efforts to overcome the obstacles encountered in the process of writing anecdotal text based on the 2013 Curriculum and its 2016 revision in class X SMK Negeri 1 Gondang Sragen. This qualitative research used a case study approach. The data sources in this research were events (the process of writing anecdote text), informants (teachers and students), and documents (the syllabus and lesson plan). The results show that the implementation of learning to write anecdotal text based on the 2013 Curriculum and its 2016 revision needs a more in-depth assessment in order to improve planning, implementation, and assessment. It is also based on the encountered obstacles occurred in the learning processes. Thus, the implementation of the 2013 Curriculum and its 2016 revision is in line with the concepts and regulations of the government. This is also implied for the achievement of national education objectives.

Penelitian ini bertujuan untuk mendeskripsikan dan menjelaskan pembelajaran menulis teks anekdot Kurikulum 2013 revisi 2016 yang dilakukan oleh guru mata pelajaran bahasa Indonesia di kelas X SMK Negeri 1 Gondang Kabupaten Sragen, kendala-kendala, serta upaya-upaya yang dilakukan oleh guru. Penelitian kualitatif ini menggunakan pendekatan studi kasus. Sumber data penelitian ini adalah peristiwa pembelajaran menulis teks anekdot, informan (guru dan siswa), dan dokumen (silabus dan RPP). Hasil penelitian menyimpulkan bahwa implementasi Kurikulum 2013 revisi 2016 pada pembelajaran menulis teks anekdot masih membutuhkan pengkajian lebih mendalam supaya dapat meningkatkan perbaikan implementasi, baik dari perencanaan, pelaksanaan, maupun penilaian mengingat masih sering adanya kendala-kendala yang dijumpai dalam pembelajaran. Dengan demikian, implementasi Kurikulum 2013 revisi 2016 yang sejalan dan selarasdengan tata konsep dan peraturan yang sudah ditentukan pemerintah dapat terwujud, juga berimplikasi pada ketercapaian tujuan pendidikan nasional.

Copyright () 2018 Institut Agama Islam Negeri Syekh Nurjati Cirebon. All rights reserved

\section{PENDAHULUAN}

Kurikulum sering diidentikkan dengan bahan ajar atau buku-buku pelajaran. Kurikulum pertama kali digunakan pada dunia olahraga zaman Yunani kuno yang berasal dari kata curir dan curere (Sanjaya, 2008). Kurikulum berkaitan erat dengan usaha mengembangkan peserta didik sesuai dengan tujuan yang ingin dicapai. Pendidikan di 


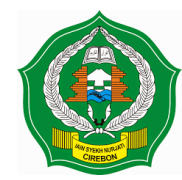

Indonesian Language Education and Literature e-ISSN: 2502-2261

http://www.syekhnurjati.ac.id/jurnal/index.php/jeill/ Vol. 4, No. 1, Desember 2018, 22 - 35

Indonesia telah diatur dalam dalam Undang-Undang Nomor 20 Tahun 2003 tentang Sistem Pendidikan Nasional (SISDIKNAS). UU tersebut mengemukakan fungsi dan tujuan pendidikan nasional, yaitu untuk mengembangkan kemampuan dan membentuk watak serta peradaban bangsa yang bermartabat dalam rangka mencerdaskan kehidupan bangsa. Selain itu, pendidikan juga bertujuan untuk mengembangkan potensi peserta didik agar menjadi manusia yang beriman dan bertakwa kepada Tuhan yang Maha Esa, berakhlak mulia, sehat, berilmu, cakap kreatif, mandiri, dan menjadi warga negara yang demokratis serta bertanggung jawab.

Untuk mencapai fungsi dan tujuan pendidikan nasional tersebut diperlukan sebuah alat. Alat untuk mencapai tujuan pendidikan tersebut adalah kurikulum (Idi, 2007). Kurikulum memiliki peranan penting dalam proses pelaksaan pendidikan nasional. Sementara itu, Oliva (1997) menyebutkan definisi kurikulum sebagai "Curriculum itself is a construct or concept, a verbalization of an extremely complex idea or set of ideas. "Hal senada juga diungkapkan oleh Arifin (2012) bahwa sistem pendidikan nasional dipandang sangat strategis dan vital karena kurikulum akan mengarahkan semua kegiatan pendidikan, termasuk sarana dan prasarana serta orang-orang yang terlibat di dalamnya untuk mencapai tujuan pendidikan. Kedudukan kurikulum dapat juga dilihat dari sistem pendidikan itu sendiri. Pendidikan sebagai sistem tentu memiliki berbagai komponen yang saling berhubungan dan saling ketergantungan. Komponen-komponen pendidikan, meliputi: tujuan pendidikan, kurikulum pendidikan, peserta didik, lingkungan, sarana dan prasarana, manajemen, dan teknologi. Komponen-komponen tersebut dapat terlaksana melalui proses pengajaran.

Kurikulum 2013 adalah sebuah kurikulum yang dirancang untuk menyiapkan peserta didik dalam menghadapi tantangan di masa depan. Pemerintah melalui menteri pendidikan dan kebudayaan merasa perlu menyiapkan kurikulum yang lebih mumpuni dibanding kurikulum sebelumnya. Salah satu alasan adanya Kurikulum 2013 diperlukan adalah adanya tuntutan masa depan dan kompetensi masa depan. Tantangan masa depan, yaitu tuntutan globalisasi, kemajuan teknologi informasi, ekonomi berbasis pengetahuan serta pergeseran kekuatan ekonomi dunia yang harus diperhitungkan dalam pengembangan kurikulum. Sementara tuntutan kompetensi masa depan sangat berbeda dengan tuntutan keterampilan di abad ke-20. Keterampilan-keterampilan tersebut adalah berkomunikasi, kemampuan memecahkan masalah, inovatif dan kreatif serta menguasai teknologi 


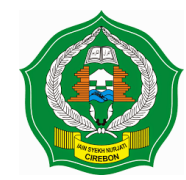

Indonesian Language Education and Literature e-ISSN: 2502-2261

http://www.syekhnurjati.ac.id/jurnal/index.php/jeill/ Vol. 4, No. 1, Desember 2018, 22 - 35

informasi. Di samping itu, isu-isu etika, sosial, politik, dan hukum dalam dunia global menjadi perhatian penting. Maka dari itu, Kurikulum 2013 berperan mempersiapkan insan Indonesia untuk memiliki kemampuan hidup sebagai pribadi dan warga negara yang produktif, kreatif, inovatif, dan efektif serta mampu berkontribusi pada kehidupan bermasyarakat, berbangsa, bernegara dan peradaban dunia tersebut.

Kurikulum 2013 revisi 2016 merupakan pembaharuan dan perbaikan dari kurikulum 2013 sebelumnya. Pembaharuan dilakukan guna memperbaiki sistem pendidikan yang diterapkan. Isi atau konten kurikulum 2013 revisi 2016 yang tertulis dalam Permendikbud Nomor 24 Tahun 2016 tentang Kompetensi Inti dan Kompetensi Dasar Pelajaran pada Kurikulum 2013 pada Pendidikan Dasar dan Pendidikan Menengah. Kompetensi dinyatakan dalam bentuk Kompetensi Inti (KI) yang merupakan gambaran secara kategorial mengenai kompetensi dalam aspek sikap, pengetahuan, dan keterampilan. Kemampuan kognitif dan psikomotor harus dipelajari peserta didik untuk suatu jenjang sekolah, kelas, dan mata pelajaran. KI dirinci lebih lanjut dalam Kompetensi Dasar (KD) yang harus dipelajari peserta didik untuk suatu tema pada jenjang SD/MI, dan untuk mata pelajaran di kelas tertentu untuk SMP/MTS, SMA/MA, SMK/MAK.

Pembelajaran Bahasa Indonesia dalam Kurikulum 2013 revisi 2016 masih sama dengan kurikulum 2013, yakni menerapkan pembelajaran berbasis teks yang didasarkan pada prinsip: bahasa dipandang sebagai teks, pemilihan bentuk kebahasaan untuk mengungkapkan makna, bahasa bersifat fungsional, dan bahasa merupakan sarana pembentukan kemampuan berpikir. Bahasa Indonesia dipandang sebagai wahana untuk mengekspresikan pemikiran, baik secara lisan maupun tulisan.

Pembelajaran Bahasa Indonesia pada dasarnya diarahkan untuk dapat menguasai empat keterampilan berbahasa, yaitu menyimak, membaca, berbicara, dan menulis. Menulis ialah menurunkan atau melukiskan lambang-lambang grafik yang menggambarkan suatu bahasa yang dipahami oleh seseorang, sehingga orang-orang lain dapat memahami lambang-lambang grafik tersebut (Tarigan, 2013). Sejalan dengan pendapat tersebut, Andayani (2015) mengatakan bahwa menulis adalah menurunkan atau melukiskan lambang-lambang grafik yang menggambarkan suatu bahasa yang dipahami oleh seseorang sehingga orang lain dapat memahami bahasa dan gambaran grafik tersebut. Jadi, menulis adalah keterampilan berbahasa setelah keterampilan menyimak, berbicara, 


\section{Indonesian Language Education and Literature e-ISSN: 2502-2261 \\ http://www.syekhnurjati.ac.id/jurnal/index.php/jeill/ Vol. 4, No. 1, Desember 2018, 22 - 35}

dan membaca yang merupakan proses kreatif bersifat produktif untuk menurunkan atau melukiskan lambang-lambang grafik berbentuk bahasa tulis untuk tujuan tertentu.

Tujuan utama dalam kegiatan menulis adalah sebagai alat komunikasi secara tidak langsung. Penulis dan pembaca dapat berkomunikasi melalui tulisan. Hal ini berpijak pada prinsip menulis adalah menyampaikan pesan penulis kepada pembaca, sehingga pembaca memahami maksud yang dituangkan atau maksud yang disampaikan melalui tulisan tersebut (Kusumaningsih, dkk., 2013). Dalam proses komunikasi tersebut penulis menyampaikan ide, gagasan, perasaan, dan pengalaman kepada pembaca. Oleh karena itu, pembelajaran menulis tidak dapat dilakukan secara instan. Kegiatan menulis merupakan keterampilan berbahasa yang paling sulit dikuasai oleh para siswa (Wardiani \& Mulyaningsih, 2015). Satu-satunya cara mengajar menulis adalah lewat latihan menulis.

Kurikulum 2013 tidak merinci keterampilan berbahasa yang harus dikuasai seperti pada KTSP. Akan tetapi, pada setiap materi jenis teks terdapat kompetensi dasar memproduksi teks. Silabus kurikulum 2013 revisi 2016 menyebut teks anekdot untuk kelas $\mathrm{X}$ tingkat SMA/SMK/MA. Teks anekdot merupakan teks yang memaparkan cerita singkat yang menarik karena lucu dan mengesankan yang isinya berupa kritik atau sindiran terhadap kebijakan, layanan publik, perilaku penguasa, atau suatu fenomena atau kejadian (Priyatni, 2014). Menulis teks anekdot termasuk jenis teks baru dalam pembelajaran bahasa Indonesia Kurikulum 2013. Priyatni (2014) mengungkapkan kekhasan struktur isi teks anekdot, yaitu: 1) Judul, judul teks anekdot biasanya singkat, padat, langsung merujuk hal/ objek yang hendak dianekdotkan; 2) Abstrak, teks anekdot termasuk dalam kategori teks narasi. Biasanya, teks anekdot diawali dengan abstrak yang berisi uraian ringkas tentang objek atau hal yang hendak disindir atau di kritik; 3) Orientasi, cerita dilanjutkan dengan pengenalan terhadap pelaku dan peristiwa; 4) Krisis, memuat tahapan peristiwa dan cerita mulai memuncak dan hampir menuju ke penyelesaian; 5) Reaksi, jawaban terhadap permasalahan yang diajukan pada tahap krisis. Ini merupakan inti kritik yang memuat unsur lucu/ mengesankan dan merupakan inti sindiran/ kritik; 6) Koda, berisi penutup, yang merupakan penegasan terhadap hal yang di kritik/ disindir.

Permasalahan dalam pembelajaran menulis memang masih dominan daripada keterampilan berbahasa lainnya. Beberapa siswa kesulitan mengungkapkan gagasan dalam bentuk tulisan. Permasalahan tersebut memerlukan adanya deskripsi pembelajaran menulis di sekolah. Keberlangsungan suatu pembelajaran sudah barang pasti dipengaruhi oleh 


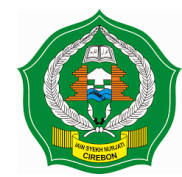

Indonesian Language Education and Literature

e-ISSN: 2502-2261

http://www.syekhnurjati.ac.id/jurnal/index.php/jeill/

Vol. 4, No. 1, Desember 2018, 22 - 35

beragam faktor, diantaranya: rencana pelaksaaan pembelajaran, bahan ajar, metode pembelajaran, media pembelajaran, kondisi peserta didik, dan pendidik itu sendiri. Pemilihan bahan ajar, metode, serta media yang kurang pas hanya akan menimbulkan permasalahan pembelajaran. Pemilihan komponen-komponen itu sebaiknya memperhatikan hal-hal, seperti: kebutuhan peserta didik, minat, dan lingkungan belajar. Metode ceramah oleh guru memang diperlukan siswa dalam pembelajaran, tetapi tidak terus-menerus dilakukan. Hal ini mengingat siswa dalam Kurikulum 2013 revisi 2016 adalah sebagai subjek pembelajaran yang aktif. Oleh karena itu, guru diharapkan mampu merancang pembelajaran yang menarik, kreatif, dan aktif sehingga pembelajaran siswa tidak pasif.

Implementasi Kurikulum 2013 revisi 2016 yang baru dilaksanakan itu sudah barang pasti masih mengalami kendala, baik dalam perencanaan, pelaksanaan, maupun penilaian yang berpengaruh pada jalannya implementasi kurikulum. Ketiga komponen tersebut adalah satu kesatuan yang tak bisa dipisahkan, saling berkaitan, serta saling memengaruhi. Kendala yang timbul dapat bersumber dari diri peserta didik, pendidik, ataupun kendala luar lainnya, seperti: sarana dan prasarana, sumber belajar, waktu pembelajaran, dan lain sebagainya. Jadi, peran strategi diperlukan untuk mengatasi kendala-kendala itu.

\section{METODE}

Penelitian ini dilaksanakan di SMK Negeri 1 Gondang Kabupaten Sragen dengan mengambil waktu penelitian yang disesuaikan program semester gasal tahun pelajaran 2016/2017. Penelitian ini merupakan penelitian kualitatif dengan pendekatan studi kasus tunggal terpancang. Arifin (2012) menyebut bahwa studi kasus merupakan studi mendalam dan komprehensif mengenai peserta didik, kelas atau sekolah yang mempunyai kasus tertentu. Adapun sumber data dalam penelitian ini, yaitu peristiwa pembelajaran menulis teks anekdot, informan yakni guru dan siswa, serta dokumen berupa silabus dan RPP. Teknik pengambilan sampel penelitian ini adalah purposive sampling. Sementara itu, teknik pengumpulan data yang digunakan adalah observasi, wawancara, analisis dokumen, dan angket. Uji validitas data menggunakan triangulasi data, triangulasi metode, dan review informan. Teknik analisis data yang digunakan adalah model analisis interaktif dengan tahapan, berupa: pengumpulan data, reduksi data, penyajian data, dan penarikan simpulan. 


\section{HASIL DAN PEMBAHASAN}

Dinamika pembaharuan Kurikulum 2013 sampai saat ini tentunya dilatarbelakangi oleh berbagai macam alasan yang sudah dikaji pemerintah sehingga melahirkan Kurikulum 2013 revisi 2016. Konsep perubahan ini memberikan angin segar bagi perjalanan kurikulum dan perbaikan pendidikan di Indonesia. Problematika, baik dalam implementasi KTSP maupun Kurikulum 2013 sebelumnya sudah dikaji sebagai bahan evaluasi kurikulum. Kurikulum 2013 revisi 2016 dikembangkan untuk menghadapi beragam permasalahan dan tantangan masa depan yang semakin kompleks. Kurikulum 2013 revisi 2016 diharapkan dapat memberi umpan positif bagi peserta didik supaya menjadi generasi penerus yang berkualitas lewat penyeimbangan yang proporsional pada kompetensi sikap, pengetahuan, dan keterampilan.

Hasil studi yang dilakukan Law (2010) menyimpulkan adanya kondisi spesifik dalam pengembangan kurikulum berbasis sekolah. Pengembangan kurikulum sekolah di China merupakan tanggung jawab guru dan sekolah. Partisipasi guru terhambat oleh gaya kepemimpinan dan kedudukan pemimpin yang terlibat dalam tim pengembang. Hal ini relevan dengan pengembangan Kurikulum 2013 yang berorientasi pada masa depan peserta didik.

Pendidik dan peserta didik saling berkelindan. Perencanaan pembelajaran disiapkan oleh guru. Pelaksanaan dilakukan oleh keduanya. Penilaian atau evaluasi yang dilakukan guru dengan tidak lupa siswa mampu memberikan feedback untuk memonitor ketercapaian atau hasil pembelajaran yang telah dilakukan. Tugas pokok guru dalam implementasi Kurikulum 2013 revisi 2016 benar-benar harus dilaksanakan oleh setiap guru demi berjalannya implementasi Kurikulum 2013 revisi 2016 yang sesuai dengan regulasi yang ditetapkan pemerintah.

\section{Pembelajaran}

Ada tiga tahapan pokok dalam implementasi kurikulum, yakni tahap perencanaan, tahap pelaksanaan, serta tahap evaluasi. Pertama, tahap perencanaan adalah tolak ukur serta pedoman dalam pelaksanaan pembelajaran. Tahap ini direncanakan secara tertulis dalam bentuk RPP, tetapi penyusunannya harus tetap diperhatikan secara mendetail. Pemilihan kompetensi dasar, materi ajar, media pembelajaran, metode pembelajaran, sumber belajar, serta cara penilaian perlu diperhatikan. RPP yang dimiliki guru Bahasa 


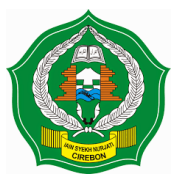

Indonesian Language Education and Literature

e-ISSN: 2502-2261

http://www.syekhnurjati.ac.id/jurnal/index.php/jeill/

Vol. 4, No. 1, Desember 2018, 22 - 35

Indonesia di SMK Negeri 1 Gondang Kabupaten Sragen dikembangkan bersama Tim Musyawarah Guru Mata Pelajaran (MGMP) Bahasa Indonesia SMK se-Kabupaten Sragen. Perumusan RPP dikembangkan berdasarkan silabus yang sudah disiapkan oleh pemerintah beserta panduannya.

Hasil analisis RPP yang telah disusun oleh guru Bahasa Indonesia di SMK Negeri 1 Gondang Kabupaten Sragen menunjukkan bahwa sebagian besar penyusunan RPP telah mengikuti kaidah-kaidah yang tertuang dalam Permendikbud Nomor 22 Tahun 2016 Tentang Standar Proses Pendidikan Dasar dan Menengah. Walaupun demikian, ketidaksesuaian perumusan deskripsi dalam RPP juga masih ditemukan, yakni pada perumusan materi ajar, media belajar, dan sumber belajar yang dianggap belum memperhatikan aspek tertentu. Selain itu, ketidaksesuaian pada sistematika, format RPP, serta metode pembelajaran dalam RPP tersebut. Seharusnya substansi metode pembelajaran tidak berdiri sendiri, tetapi terintegrasi dalam langkah-langkah kegiatan pembelajaran. Implementasi setiap kurikulum akan menghadapi banyak masalah. Tahap Perencanaan akan membantu mengidentifikasi cara-cara mengatasi masalah dan sekaligus membantu mengurangi masala-masalah yang akan muncul di dalam implementasi kurikulum.

Kedua, tahap pelaksanaan mencakup atas kegiatan pendahuluan, inti, dan penutup. Ketiganya adalah serangkaian langkah-langkah pembelajaran yang saling berkaitan dalam menentukan jalannya pembelajaran. Permendikbud Nomor 22 Tahun 2016 tentang Standar Proses Pendidikan Dasar dan Menengah telah mengatur tata pelaksanaan ketiga tahap kegiatan tersebut. Kegiatan pendahuluan dilakukan guru Bahasa Indonesia di SMK Negeri 1 Gondang Kabupaten Sragen di antaranya dengan mengucapkan salam, bertanya kabar, bertanya kehadiran peserta didik baik dari segi kuantitas. Guru menghubungkan materi yang sebelumnya telah dipelajari dengan materi yang akan disampaikan. Guru bertanya mengenai kesulitan atau ketidakpahaman peserta didik terhadap materi sebelumnya. Guru mengutarakan manfaat pembelajaran serta mendemonstrasikan materi pembelajaran yang dikaitkan dengan isu-isu terkini yang faktual dalam bidang ekonomi, sosial, dan politik. Sebelum menginjak pada materi yang dituju, guru mengutarakan kompetensi yang hendak dicapai. Selain itu, penyampaian garis besar kegiatan juga dilakukan guru pada pembelajaran tersebut beserta dengan keruntutan dan kedetailan materi yang akan dipelajari. Data tersebut dapat menjadi benang merah yang menunjukkan bahwa sebagian 


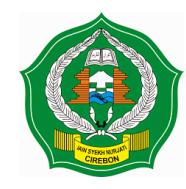

Indonesian Language Education and Literature

e-ISSN: 2502-2261

http://www.syekhnurjati.ac.id/jurnal/index.php/jeill/

Vol. 4, No. 1, Desember 2018, 22 - 35

besar kegiatan pendahuluan sudah dilakukan secara baik sesuai konsep dan ketentuan Permendikbud Nomor 22 Tahun 2016.

Kegiatan berikutnya adalah kegiatan inti sebagai kegiatan kedua. Kegiatan inti dalam kurikulum 2013 revisi 2016, yaitu pembelajaran yang menggunakan model pembelajaran, metode pembelajaran, media pembelajaran, dan sumber belajar yang disesuaikan dengan karakteristik peserta didik dan mata pelajaran. Pemilihan pendekatan pembelajaran disesuaikan dengan karakteristik kompetensi dan jenjang pendidikan. Dalam pembelajaran anekdot guru Bahasa Indonesia di SMK Negeri 1 Gondang Kabupaten Sragen menerapkan pendekatan saintifik yang meliputi lima tahap, yaitu: menanya, mengamati, mengumpulkan informasi, mengasosiasi, dan mengkomunikasikan. Deskripsi tahap kegiatan inti dalam pembelajaran menulis teks anekdot, meliputi: 1) tahap mengamati, guru mengarahkan peserta didik untuk membaca dan memahami unsur intrinsik dan contoh teks anekdot yang ada dibuku siswa; 2) tahap menanya, guru memberikan kesempatan seluas-luasnya kepada peserta didik untuk bertanya, namun tak ada yang bertanya; 3) tahap mengumpulkan informasi, guru mengarahkan peserta didik untuk mengumpulkan informasi berdasarkan topik yang akan diangkat dalam penulisan teks anekdot; 4) tahap mengasosiasi data guru telah menyediakan lembar kerja tempat peserta didik menulis data yang telah dikumpulkan dalam lembar kerja tersebut lalu dilanjutkan dengan mulai menyusun teks anekdot sesuai dengan unsur intrinsik; 5) tahap mengomunikasikan, peserta didik diberi kesempatan untuk mempresentasikan hasil tulisannya dan guru juga memberi kesempatan kepada peserta didik lain untuk menanggapi teks anekdot yang telah dipresentasikan siswa tersebut.

Pada tahap kegiatan penutup dalam Kurikulum 2013 revisi 2016, guru bersama peserta didik, baik secara individual maupun kelompok melakukan refleksi untuk mengevaluasi: 1) seluruh rangkaian aktivitas pembelajaran dan hasil-hasil yang diperoleh untuk selanjutnya secara bersama menemukan manfaat langsung maupun tidak langsung dari hasil pembelajaran yang telah berlangsung; 2) memberikan umpan balik terhadap proses dan hasil pembelajaran; 3) melakukan kegiatan tindak lanjut dalam bentuk pemberian tugas, baik tugas individual maupun kelompok; dan 4) menginformasikan rencana kegiatan pembelajaran untuk pertemuan berikutnya. Dalam kegiatan penutup pembelajaran anekdot ini guru menyampaikan kritik dan saran atas hasil karya tulis siswa 


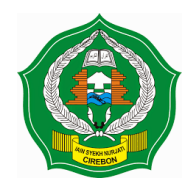

Indonesian Language Education and Literature

e-ISSN: 2502-2261

http://www.syekhnurjati.ac.id/jurnal/index.php/jeill/

Vol. 4, No. 1, Desember 2018, 22 - 35

dan memerintahkan perbaikan kepada siswa yang belum sesuai dengan unsur pembentuk dalam penulisan teks anekdot.

\section{Penilaian}

Pada tahap penilaian ini, guru bahasa Indonesia di SMK Negeri 1 Gondang Kabupaten Sragen sudah melakukan penilaian sesuai dengan indikator dan instrumen yang telah ditentukan dalam RPP. Penyusunan instrumen penilaian telah dilengkapi dengan pedoman penilaian. Sebagai tahap akhir dalam pembelajaran, penilaian menajdi bahan evaluasi guna mengukur kompetensi dasar peserta didik beserta dengan indikator yang telah dilaksanakan pada proses pembelajaran. Dalam pembelajaran menulis teks anekdot, guru memanfaatkan teknik penilaian berupa portofolio guna menilai produk teks anekdot yang dihasilkan peserta didik, baik secara kelompok maupun individu sesuai dengan indikator pencapaian kompetensi. Pedoman pemberian skor penilaian keterampilan menulis teks anekdot telah dilengkapi dengan aspek yang dinilai, skor, serta kriteria penilaian. Jadi, guru mampu menentukan langkah keberlanjutan terhadap pembelajaran yang telah dilakukannya.

Berdasarkan hasil kajian, dapat dilihat bahwa pelaksanaan pembelajaran menulis teks anekdot di kelas X SMK Negeri 1 Gondang Kabupaten Sragen secara keseluruhan telah berjalan sesuai dengan rencana. Meskipun demikian, terdapat beberapa temuan komponen yang pelaksanaannya tidak sesuai dengan rencana dalam RPP, yakni pada pemanfaatan sumber belajar, media pembelajaran, dan sintak model pembelajaran yang diterapkan. Hal ini bisa menjadi evaluasi perbaikan atas pelaksanaan pembelajaran dalam Kurikulum 2013 revisi 2016 supaya jalannya pembelajaran berhasil dan terwujud sesuai dengan yang diharapkan.

\section{Kendala dan Upaya Mengatasi Kendala}

Beragam kendala dalam pembelajaran di kurikulum 2013 revisi 2016 menjadi tantangan kerja tersendiri bagi pendidik. Permasalahan atau kendala khususnya pada pembelajaran menulis teks anekdot dapat dilihat, baik dari tahap perencanaan, tahap pelaksanaan, maupun tahap penilaian. Berikut permasalahan yang dialami guru pada tahap perencanaan, antara lain: penyesuaian format dan sistematika RPP serta penentuan alokasi waktu. Tahap pelaksanaan pun juga tak luput dari yang namanya permasalahan, kendala yang dihadapi guru adalah penentuan metode pembelajaran dan alokasi waktu yang diterapkan pada kegiatan inti. Selain itu, kendala pada tahap penilaian yang guru temukan adalah 
Indonesian Language Education and Literature

e-ISSN: 2502-2261

http://www.syekhnurjati.ac.id/jurnal/index.php/jeill/

Vol. 4, No. 1, Desember 2018, $22-35$

kompleksitas penilaian yang mendetail sehingga guru wajib mengolah nilai yang kuantitasnya begitu banyak serta memerlukan waktu yang bisa dikatakan cukup lama.

Kendala tidak hanya berasal dari guru. Peserta didik juga menjadi pemicu timbulnya permasalahan. Permasalahan dari peserta didik dipengaruhi oleh faktor internal dan eksternal. Faktor internal itu sendiri ialah konsentrasi siswa, minat, dan pemahamannya. Sementara itu, faktor eksternal ada pada pengembangan paragraf serta pemanfaatan bahasa yang tepat. Lingkungan kelas dan sekolah, sumber belajar, waktu pembelajaran, serta kurangnya sarana prasarana menjadi kendala tersendiri yang berhulu dari kontrol guru dan peserta didik. Hal tersebut sesuai dengan hasil penelitian Bennie dan Newstead (1999) yang menyatakan bahwa kendala-kendala implementasi kurikulum baru, terutama terkait dengan kekurangjelasan substansi isi kurikulum yang berimplikasi pada implementasi, kekurangsiapan guru, kondisi kemampuan siswa, serta budaya sekolah. Jadi, permasalahan tersebut harus diatasi dengan beragam strategi supaya proses implementasi kurikulum ini mampu dilakukan sesuai dengan kaidah yang telah ditentukan.

Beragam strategi ditempuh sebagai upaya menanggulangi kendala dan mengoptimalkan pembelajaran menulis teks anekdot dalam pengimplementasian kurikulum 2013 revisi 2016. Berkaitan dengan hal tersebut, peran guru ialah sebagai fasilitator dan menduduki posisi penting dalam hal pengelolaan bahan pembelajaran karena hampir seluruhnya bertumpu pada guru (Mulyasa, 2014). Upaya yang dilakukan guru sebagai berikut ini. Pada tahap perencanaan, RPP harus dimaksimalkan perumusannya oleh pendidik dengan acuan Permendikbud Nomor 22 Tahun 2016 mengenai Standar Proses Pendidikan Dasar dan Menengah. Hal ini dikarenakan silabus sudah disiapkan oleh pemerintah, baik kurikulum nasional maupun untuk kurikulum wilayah sehingga guru tinggal mengembangkan rencana pembelajaran yang tidak terlalu jelimet (Mulyasa, 2014: 181). Selain itu, dalam hal pembagian alokasi waktu. Guru harus mampu menyelesaikan dengan mempertimbangkan aspek-aspek, di antaranya jumlah hari yang efektif, jumlah KD, serta tingkat kedalaman materi ajar supaya pengalokasian waktu yang telah direncanakan menjadi tepat.

Dalam mengatasi permasalahan metode, upaya yang guru lakukan ialah dengan memilah dan memilih metode yang tepat guna dalam pembelajaran bahasa Indonesia dengan menyesuaikan karakteristik peserta didik. Selain itu, guru wajib menciptakan 


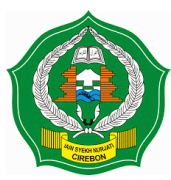

Indonesian Language Education and Literature

e-ISSN: 2502-2261

http://www.syekhnurjati.ac.id/jurnal/index.php/jeill/

Vol. 4, No. 1, Desember 2018, 22 - 35

keterpusatan pembelajaran pada peserta didik agar kreativitas peserta didik terlihat lebih optimal. Hal ini dalam rangka menghasilkan produk tulis berupa teks anekdot. Dalam penerapan alokasi waktu pembelajaran pada kegiatan inti, guru dapat mengupayakan tindakan belajar yang tidak memunculkan pengalaman belajar secara keseluruhan hanya dalam satu kali pertemuan. Hal itu dapat ditindaklanjuti pada tahap pertemuan selanjutnya dengan tidak bergantung pada banyaknya cakupan materi ajar.

Pada tahap penilaian, guru mampu mengatasi permasalahan dengan upaya mendalami kajian dan mempelajari lebih detail terhadap panduan yang telah tertuang dalam Pemendikbud Nomor 23 Tahun 2016 mengenai Standar Penilaian Pendidikan. Penilaian autentik mempunyai sifat holistik dan utuh yang meliputi aspek afektif atau sikap, kognitif atau pengetahuan, serta psikomotorik atau keterampilan. Penilaian autentik ini akan berimplikasi terhadap proses penilaian yang dikerjakan guru berdasarkan pedoman kriteria.

Kendala dalam pembelajaran yang berasal dari peserta didik dipengaruhi oleh faktor internal dan faktor eksternal. Kendala yang bersumber dari faktor internal ialah konsentrasi peserta didik, pemahaman, dan minat. Sementara itu, kendala yang bersumber dari faktor eksternal peserta didik adalah pengembangan paragraf dan pemanfaatan bahasa baku. Kendala lainnya merupakan kendala yang berasal dari luar kendali pendidik dan peserta didik seperti lingkungan kelas, lingkungan sekolah, sumber belajar, waktu pembelajaran, serta sarana dan prasarana belajar.

Berdasarkan faktor internal tersebut, guru berupaya mengatasi kendala yang ditemui peserta didik selama pembelajaran berlangsung. Perihal kendala konsentrasi belajar, guru melakukan strategi dengan cara memberikan pengarahan yang terpusat agar perserta didik lebih terfokus dalam belajar. Guru memilih dan memanfaatkan metode yang tepat, membuat pembelajaran yang menarik perhatian dengan memanfaatkan media pembelajaran, serta pengelolaan kelas yang kondusif. Perihal kendala pemahaman, guru menerangkan penjelasan secara personal kepada peserta didik yang belum paham, memberikan kesempatan peserta didik untuk bertanya, komunikasi dua arah yang efektif antara guru dan peserta didik, serta pengintegrasian materi ajar yang erat kaitannya dengan kehidupan nyata peserta didik. Perihal menumbuhkan minat peserta didik terhadap pembelajaran, upaya yang guru lakukan adalah memotivasi peserta didik secara intens dengan tidak mengurangi pandangan terhadap latar belakang peserta didik. Tumbuh kembang minat peserta 


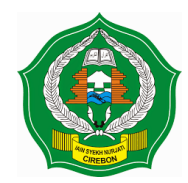

Indonesian Language Education and Literature

e-ISSN: 2502-2261

http://www.syekhnurjati.ac.id/jurnal/index.php/jeill/

Vol. 4, No. 1, Desember 2018, 22 - 35

didik juga diupayakan guru melalui pembelajaran yang menarik dan menyenangkan sehingga peserta didik berantusias dan tertarik terhadap pembelajaran.

Berdasarkan faktor eksternal tersebut, upaya yang guru lakukan untuk mengatasi kendala pengembangan paragraf, yakni dengan meningkatkan kembali materi tentang struktur anekdot beserta jenis-jenis paragraf yang sesuai dengan letak kalimat utama. Guru juga menunjukkan dan menerangkan kembali pelajaran sebelumnya tentang pembuatan alur bagan sebagai sarana strategi untuk mengembangkan paragraf. Dalam hal kendala penggunaan bahasa baku, guru menggunakan strategi pencontohan atau memberikan contoh kepada peserta didik, juga mengkondisikan peserta didik untuk terbiasa berkomunikasi lisan ataupun tulisan yang senantiasa menpergunakan bahasa Indonesia yang baik dan benar.

Sementara itu, upaya untuk menanggulangi kendala di luar kendali guru dan peserta didik, seperti: lingkungan belajar yakni dengan memanfaatkan lingkungan sebagai sumber belajar. Kendala sumber belajar, guru menggunakan strategi berupa arahan kepada peserta didik tentang sumber belajar mana yang dapat dirujuk sebagai dukungan materi pembelajaran menulis teks anekdot. Perihal kendala waktu pembelajaran diselesaikan guru melalui penyesuaian kondisi peserta didik saat pembelajaran siang atau menjelang sore dengan menciptakan pembelajaran yang lebih intens. Selain itu, pembelajaran pada waktu siang atau menjelang sore dapat dilakukan dengan baik oleh peserta didik jika guru tidak memberikan tugas yang berat. Fasilitas dan sumber belajar yang masih menjadi kendala bukan hanya tanggung jawab pemerintah, tetapi juga menjadi tanggung jawab masyarakat sekolah untuk dapat terus berimprovisasi, berinisiatif, berkreasi, serta berinovasi dalam rangka menyikapi keterbatasan sarana dan prasarana, sehingga implementasi Kurikulum 2013 revisi 2016 ini dapat berjalan dengan baik.

\section{SIMPULAN}

Pembelajaran menulis teks anekdot mencakup tiga tahap, yakni tahap perencanaan, pelaksanaan, dan penutup. Simpulan yang dapat diambil berdasarkan temuan, analisis, serta pembahasan adalah format dan sistematika dalam RPP yang dirumuskan oleh guru di SMK Negeri 1 Gondang Kabupaten Sragen secara garis besar telah sesuai dengan prinsip perumusan RPP yang tertuang dalam Permendikbud Nomor 22 Tahun 2016 mengenai Standar Proses Pendidikan Dasar dan Menengah. Kendati demikian, ketidaksesuaian 


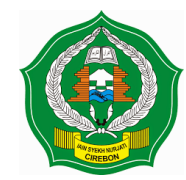

Indonesian Language Education and Literature e-ISSN: 2502-2261

http://www.syekhnurjati.ac.id/jurnal/index.php/jeill/ Vol. 4, No. 1, Desember 2018, 22 - 35

seperti pada penentuan sumber belajar, media, serta metode pembelajaran juga masih ditemukan. Kendala atau permasalahan selama pembelajaran bersumber dari guru, peserta, dan faktor luar dari keduanya. Kendala dari guru mencakup kesesuaian format dan sistematika perumusan RPP, metode pembelajaran yang dipilih, alokasi waktu yang dibagi, serta kompleksitas penilaian yang juga harus detail. Permasalahan dari peserta didik mencakup minat belajar, konsentrasi, keterpahaman, pengembangan paragraf, serta pemakaian bahasa baku. Kendala di luar kendali guru dan peserta didik mencakup lingkungan kelas dan sekolah, sumber belajar, waktu belajar, serta sarana dan prasarana.

\section{DAFTAR PUSTAKA}

Andayani. (2015). Problema dan Aksioma dalam Metodologi Pembelajaran Bahasa Indonesia. Yogyakarta: Penerbit Deepublish.

Arifin, Z. (2012). Konsepdan Model Pengembangan Kurikulum.Bandung: RemajaRosdakarya.

Bennie, K. \& Newstead, K. (1999). Obstacles to Implementation a New Curriculum. www.academic.sun.ac.za. Diakses 21 Juni 2017.

Idi, A. (2007). Pengembangan Kurikulum: Teori dan Praktik. Jogjakarta: Ar-Ruzz Media.

Kusumaningsih, dkk. (2013). Terampil Berbahasa Indonesia. Yogyakarta: Penerbit ANDI.

Law, E. H. F, Wan, S. W. Y, Galton, M, \& Lee, J C.K. (2010). Managing school-based curriculum innovations: a Hong Kong case study. Curriculum Journal, Vol. 21, Issue 3, 2010. http:// www.tandf.co.uk/journals/titles.

Mulyasa. (2014). Pengembangan dan Implementasi Kurikulum 2013. Bandung: PT Remaja Rosdakarya.

Oliva, P. F. (1997). Developing The Curriculum (Third edition). Harper Collins Publishers: United States

Peraturan Menteri Pendidikan dan Kebudayaan Nomor 22 Tahun 2016 tentang Standar Proses Pendidikan Dasar dan Menengah.

Peraturan Menteri Pendidikan dan Kebudayaan Nomor 23 Tahun 2016 tentang Standar Penilaian Pendidikan.

Peraturan Menteri Pendidikan dan Kebudayaan Nomor 24 Tahun 2016 tentang Kompetensi Dasar Pelajaran Pada Kurikulum 2013 Pada Pendidikan Dasar dan Menengah.

Priyatni, E. T. (2014). Desain Pembelajaran Bahasa Indonesia dalam Kurikulum 2013. Jakarta: PT. Bumi Aksara.

Tarigan, H. G. (2013). Menulis sebagai Suatu Keterampilan Berbahasa. Bandung: Penerbit Angkasa. 


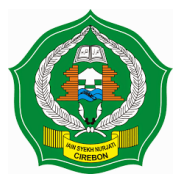

Indonesian Language Education and Literature
e-ISSN: 2502-2261 Vol. 4, No. 1, Desember 2018, 22 - 35

Sanjaya, W. (2008). Kurikulum dan Pembelajaran: Teori dan Praktik Pengembangan Kurikulum Tingkat Satuan Pendidikan (KTSP). Jakarta: Fajar Interpratama Offset.

Undang-Undang Nomor 20 Tahun 2003 tentang Sistem Pendidikan Nasional.

Wardiani, R. \& Mulyaningsih, I. (2015). Kemampuan Menulis Deskripsi (Studi Kasus di Pondok Pesantren Nuurusshiddiiq Cirebon. Indonesian Language Education and Literature, 1(1), 1 - 15. DOI: http://dx.doi.org/10.24235/ileal.v1i1.36. 